\title{
DOSSIÊ \\ Território em rede: cartografia vivida e razão de Estado no Século das Luzes
}

\section{Introdução}

\author{
Iris Kantor ${ }^{1}$ \\ Beatriz Piccolotto Siqueira Bueno ${ }^{2}$ \\ Vera Lúcia Amaral Ferlini ${ }^{3}$
}

Este dossiê coroa um trabalho de parceria interdisciplinar e interinstitucional $^{4}$, envolvendo o tema da cartografia histórica. Dá continuidade à edição anterior dos Anais do Museu Paulista - Cartografia de uma história: exercícios cartomuseográficos e releituras cosmográficas - séculos XVI e XVII -, enfocando, agora, o papel da cartografia no processo de produção do território luso-americano no Século das Luzes.

Os ensaios e reflexões compartilham de uma perspectiva teórico-metodológica comum, que compreende a documentação cartográfica como fonte para o conhecimento histórico.

Suportes e vetores do processo de formação dos Estados Dinásticos, mapas cumpriram papel estratégico, mediando, projetando e legitimando o exercício da soberania, no reino e nas conquistas ultramarinas. Expressão dos processos de territorialização dos Estados Modernos, eles mereceram investimento permanente proveniente das Coroas européias, tanto para o aperfeiçoamento das técnicas de representação como para a formação de quadros profissionais especializados na sua feitura.

Neste dossiê, procuramos articular três dimensões relacionadas à cartografia sul-americana. A primeira delas diz respeito aos usos políticos dos mapas em negociações internacionais, faceta eminentemente projetiva e nem
1. Docente do Departamento de História da Faculdade de Filosofia, Letras e Ciências Humanas da Universidade de São Paulo, curadoracientífica da exposição Cartografia de uma história - São Paulo colonial: mapas e relatos. E-mail: <ikantor@usp.br>.

2. Docente da Faculdade de Arquitetura e Urbanismo da Universidade de São Paulo, curadora-científica da exposição Cartografia de uma bistória - São Paulo colonial: mapas e relatos. E-mail: <beatrizbueno@terra.com.br>.

3. Docente do Departamento de História da Faculdade de Filosofia, Letras e Ciências Humanas da Universidade de São Paulo, coordenadora-geral da exposição Cartografia de uma bistória - São Paulo colonial: mapas e relatos. E-mail: <veferlin@usp.br>.

4. Exitosa parceria entre professores, pesquisadores e estagiários do Museu Paulista, do Departamento de His- 
tória da FFLCH, da Cátedra Jaime Cortesão e da Faculdade de Arquitetura e Urbanismo da Universidade de São Paulo, que teve início por ocasião do preparo da exposição Cartografia de uma História. São Paulo: mapas e relatos, realizada no Museu Paulista entre março de 2005 e junho de 2006

5. A inspiração do título deste módulo advém do ensaio de Vera Ferlini (2004)

6. P. Alliès (1980).

7. B. Lepetit (2001) sempre coetânea aos movimentos de ocupação e povoamento. A segunda dimensão refere-se ao processo de coleta, sistematização e elaboração de mapas, do campo ao gabinete. Por fim, uma terceira dimensão ilumina as formas de constituição e sedimentação das redes oficiais que se sobrepuseram aos espaços vividos, mapeados e previamente já ocupados.

Cada uma dessas dimensões alicerça um módulo temático. $\bigcirc$ primeiro módulo - Geopolítica e retórica nos mapas - abrange os ensaios de João Carlos Garcia e Carla Lois, de Iris Kantor, de Jorge Cintra, e de André Ferrand de Almeida. O segundo módulo - Cartografia vivenciada e produção do território -, com foco em séries cartográficas regionais, reúne os artigos de Glória Kok, Beatriz Bueno, Júnia Furtado, Maria de Fátima Costa e novamente de André Ferrand de Almeida. Explora o papel dinâmico da cartografia na lenta produção e apropriação de territórios e elucida como os mapas foram instrumentos estratégicos, enfatizando as tensões entre a razão de Estado e as realidades locais, que muitas vezes reorientaram o processo de acumulação de saberes sobre o território. O terceiro módulo -Tessitura das redes na Capitania de São Paulo: de fronteira a território ${ }^{5}$ - apresenta o artigo de Vera Ferlini e outro de Beatriz Bueno, tratando do lento processo de enraizamento das redes administrativas, sua sobreposição e hierarquização. Através de exercícios de reconstituição de dados provenientes de mapas antigos, realizados em parceria com o Inpe, explora o processo de dilatação dos confins da Capitania de São Paulo.

Termo hoje polissêmico, território é um conceito de invenção recente, raro no século XVII e generalizado no Século das Luzes, concomitante ao processo de consolidação e definição das fronteiras dos Estados europeus. Em suas origens, o neologismo referia-se a um elemento constitutivo do Estado, expressão jurídica das Coroas em processo de espacialização de suas burocracias.

Partindo do princípio de que território e espaço não são noções equivalentes, busca-se, no presente dossiê, desnaturalizar a idéia recorrente de território como algo espontâneo ou dado na natureza, e, ao contrário, sublinhar sua dimensão de artefato social.

Da vivência dos espaços à sua transformação em território, por intermédio do estudo da cartografia, os diversos artigos propiciam a visualização de um processo lento, envolvendo inúmeros atores e temporalidades distintas. A cartografia evidencia estratos de vivência e territorialidades sociais ${ }^{7}$ anteriores à presença dos colonizadores europeus. A produção e apropriação de territórios pela rede de atores coletivos e individuais, oficiais e extraoficiais, envolveu etapas sucessivas de acúmulo e/ ou dispersão de informação, que aparecem registradas nas cartas e descrições geográficas como camadas arqueológicas de vivências. Nesse sentido, a cartografia setecentista propicia ao pesquisador múltiplas linhas de investigação, desde a experiência cotidiana de devassamento dos sertões aos avatares da razão de Estado.

Se o território não é um dado da natureza, mas precisa ser construído socialmente, em mundos novos isso significou complexas formas de interação entre os saberes indígenas e os europeus. Um fenômeno singular de apropriação 
cultura $^{8}$ de territorialidades nativas ${ }^{9}$, de conhecimento e tradução de um saber em outro, de afinação de repertórios para construção de um denominador comum. Diversos documentos representam esse lento processo de intercurso culturallo, de fertilização mútua. Por intermédio da documentação cartográfica, desenha-se uma ponte entre o saber local e os desígnios da razão de Estado, interesses nem sempre harmônicos e, na maioria das vezes, tensos. Síntese dessa conjugação de linguagens e territorialidades sociais, os mapas vertebram o conhecimento sobre o espaço, dando corporeidade ao território. Decantam, selecionam, recortam, nomeiam uma natureza descontínua e ilimitada, apropriando-se dela e dando-the tangibilidade. $\bigcirc$ estudo dos topônimos exemplifica uma dimensão deste peculiar intercurso cultural supracitado. A toponímia é indígena, mas dada pelo dominador, representando as interações entre um e outro. Há na língua indígena um atributo geográfico que expressa o caráter do lugar, mas é através dos mapas do colonizador que se faz inteligível e estrategicamente eficaz para orientar a interiorização e consolidação das fronteiras de territórios coloniais em construção.

Nesse quadro, a cartografia ibérica, majoritariamente manuscrita, presta-se de maneira modelar a uma leitura processual, transversal, diassincrônica do espaço. Diferentemente da cartografia impressa, que cristaliza momentos para divulgá-los em larga escala, a tradição ibérica, sigilosa e manuscrita, levou à não estabilização da informação, espécie de trabalho constantemente em andamento (work in progress). $\bigcirc$ caráter manuscrito da cartografia ibero-americana propicia o deslocamento das tópicas espaciais, comumente mais cristalizadas em mapas impressos.

A serialização dos mapas revela o processo de devassamento e construção de contiguidades geográficas, onde o caráter "de arquipélago" da colonização é superado por uma visão de conjunto. Só na cartografia a América portuguesa se torna apreensível como realidade geográfica e jurídica. Mapas têm, portanto, papel fundamental na produção de uma territorialidade única, contínua e homogênea. Como pesquisadores, temos, hoje, posição privilegiada para observar e desconstruir essas memórias espaciais herdadas.

\section{REFERÊNCIAS}

ALLIÈS, P. L'invention du territoire. Grenoble: Presses Universitaires de Grenoble, 1980.

CERTEAU, M. Invenção do cotidiano. 2. ed. Petrópolis: Vozes, 1994.

FERLINI, V. São Paulo, de fronteira a território: uma capitania dos novos tempos. In: ANTUNES, Ermelinda (cur.). Laboratório do mundo. Idéias e saberes do século XVIII. Catálogo. São Paulo: Pinacoteca do Estado, 2004. p. 18-23.

HOLANDA, S. B. de. Movimentos de população em São Paulo no século XVIII. Revista do Instituto de Estudos Brasileiros, São Paulo, n. 1, p. 55-111, 1966.
8. M. Certeau (1994).

9. S. B. de Holanda (1966; 1994).

10. F. Novais (1997) 
LEPETIT, B. Por uma nova bistória urbana [Seleção de textos, revisão crítica e apresentação de Heliana Angotti Salgueiro]. São Paulo: Edusp, 2001.

NOVAIS, F. Condições de privacidade na Colônia. In: SOUZA, L. de M. (Org.). História da vida privada no Brasil: cotidiano e vida privada na América portuguesa, v.1. São Paulo: Companhia das Letras, 1997. 